\title{
Resistance development and insecticide susceptibility in Culexpipiens pipiens, an important vector of human diseases, against selection pressure of temephos and its relationship to cross-resistance towards organophosphates and pyrethroids insecticides
}

\author{
Ahmed Tabbabi ${ }^{1,2}$, Ali Laamari ${ }^{1}$, Raja Ben Cheikh ${ }^{1}$, Ibtissem Ben Jha ${ }^{1}$, \\ Jabeur Daaboub ${ }^{1,2}$, Hassen Ben Cheikh ${ }^{1}$
}

1. Laboratory of Genetics, Faculty of Medicine of Monastir, University of Monastir, Monastir, Tunisia.

2. Department of Hygiene and Environmental Protection, Ministry of Public Health, Tunis, Tunisia.

\begin{abstract}
Background: Culex pipiens pipiens is an important vector of human diseases.

Objective: To determine the insecticide resistance development in Culex pipiens pipiens against selection pressure of temephos.. Methods: A field population of Culex pipiens pipiens was collected from Northwestern Tunisia with a medium level of temephos resistance $\left(\mathrm{LC}_{50}=0.0069\right)$. It was subjected to six generations of temephos pressure selection to evaluate its relationship to cross-resistance towards organophosphates (OPs) and pyrethroids (PYR) insecticides.

Results: The selection was initiated at the dose $0.0266,0.0748$ and 0.0069 which were increased during successive generations up to $0.1488,3.8747$ and 0.0086 after sixth generation for temephos, chlorpyrifos and permethrin insecticides, respectively. It is important to noted that high cross-resistance to chlorpyrifos insecticide $(\mathrm{OP})$ was detected $(51.88 \times)$. However, little or no cross-resistance to the pyrethroid permethrin (PYR) was recorded (1.24×). Contrary to metabolic resistance, it seemed that acetylcholinesterases AChE 1 was fixed under pressure selection.

Conclusion: The high cross-resistance to temephos and chlorpyrifos is reasonable because they belong to the same class of insecticide (OP). However, the little cross-resistance to the pyrethroid permethrin could support its use alternately for Culex pipiens pipiens control.

Keywords: Culex pipiens pipiens, temephos selection, Tunisia.

DOI: https://dx.doi.org/10.4314/ahs.v18i4.38

Cite as: Tabbabi A, Laamari A, Cheikh RB, Jha IB, Daaboub J, Cheikh HB. Resistance development and insecticide susceptibility in Culex pipiens pipiens, an important vector of human diseases, against selection pressure of temephos and its relationship to cross-resistance towards organophosphates and pyrethroids insecticides. Afri Health Sci. 2018;18(4): 1175-1181. https:// dx.doi.org/10.4314/abs.v18i4.38
\end{abstract}

\section{Introduction}

Most frequently found in tropical and sub-tropical areas of the world, Culexpipiens historically causes nuisance and are important vectors of humans diseases ${ }^{1}$. Insecticide re-

\section{Corresponding author:}

Ahmed Tabbabi,

Laboratory of Genetics,

Faculty of Medicine of Monastir,

University of Monastir, Monastir, Tunisia.

Email: tabbabiahmed@gmail.com sistance is generally considered to undermine control of vector-transmitted diseases because it increases the number of vectors that survive the insecticide treatment and therefore increasing problem in vector control programs. The main challenge of medical entomologists is to retard the development of insecticide resistance and reduce its influence on financially limited control ${ }^{2}$. It is important to note that resistance to insecticides has appeared in every major species of mosquitoes vectors including at least in 83 anopheline and culicine species ${ }^{3}$. Researchers have shown that the development of insecticide resistance in insect populations is influenced by many biological,

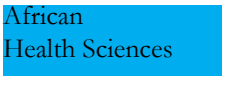

(C) 2018 Tabbabi et al. Licensee African Health Sciences. This is an Open Access article distributed under the terms of the Creative commons Attribution License (https://creativecommons.org/licenses/BY/4.0), which permits unrestricted use, distribution, and reproduction in any medium, provided the original work is properly cited. 
ecological, genetic, and operational factors such as the frequency and dominance of the resistance gene, the insecticide selection pressure and the history of pesticides exposure, the isolation, in breeding and reproductive potential of the insect population.

It is known that many chemical insecticides including organophosphates and pyrethroids are widely used for controlling mosquito population. Therefore, the evaluation of vector management programs must regularly be done to develop appropriate and comprehensive resistance assessment and management techniques in order to collectively find an alternately solution to address the existing global public health issue of insecticide resistance in the future that will prevent or minimize the development of resistance to effective insecticides ${ }^{4}$.

The objective of the present study was to determine the resistance development and insecticide susceptibility in Culexpipiens pipiens against selection pressure of temephos and its relationship to cross-resistance towards organophosphates and pyrethroids insecticides. Such knowledge is essential in defining future control strategies against this medically important mosquito. Indeed, the characterization of the resistance mechanisms and the estimation of the proportion of resistant phenotypes will be of great importance to possible choice of the insecticide to be used to retard the rapid evolution of resistance and to provide proper timing of insecticide application, respectively.

\section{Materials and methods}

\section{Mosquito strains}

A field population was collected from Boussalem (Northwestern Tunisia) and reared in laboratory condition under temephos selection pressure during six generations. S-Lab is a susceptible strain without any known resistance genes isolated from a Californian population ${ }^{5}$ in 1966. It has been maintained in laboratory and used as reference to do different comparison with field populations. Two OPs resistant strains: SA2, a resistant strain homozygous for Ester ${ }^{2}$, displaying over-produced esterases A2-B2, and SA5, a resistant strain homozygous for Ester $^{5}$, displaying over-produced esterases $\mathrm{A} 5-\mathrm{B} 5^{6}$ were used as references to identify different esterases.

\section{Mosquitoes rearing}

Collected larvae were transported to the laboratory and directly transferred into plastic trays containing distilled water with rabbit croquette which served as food under standard insectary conditions $\left(25 \pm 1^{\circ} \mathrm{C}\right.$ and $70 \pm 5 \%$ $\mathrm{RH})$. Both adult sexes have been fed on sugar water. Only females fed on blood birds. Adult mosquitoes were maintained in cages. The cycle is repeated after obtained eggs.

\section{Insecticides and synergists}

Different insecticides including the organophosphate temephos and chlorpyrifos, the pyrethroid permethrin and the carbamate propoxur were used in the present study. The effect on organophosphates resistance of 2 synergists: the DEF (98\%, Chem Service, England), and $\mathrm{Pb}$ (94\%, Laboratory Dr Ehrenstorfer, Germany), was studied by exposing larvae to a standard sub-lethal doses of $0.08 \mathrm{mg} / 1$ for $\mathrm{DEF}$, and $2.5 \mathrm{mg} / 1$ for $\mathrm{Pb}$, $4 \mathrm{~h}$ before the addition of the insecticide.

\section{Selection and bioassay procedures}

Groups of late third or early $4^{\text {th }}$-stage larvae were submitted to temephos pressure selection for $24 \mathrm{~h}$. Survivor larvae were thereafter transferred to clean water and reared to the next generation. The larval tests were carried out according to the standard method of Raymond et $\mathrm{al}^{5}$. Insecticides bioassays included 5 concentrations providing between 0 and 100\% mortality and 5 replicates per concentration on sets of 20 early $4^{\text {th }}$ instars in a total volume of $100 \mathrm{ml}$ of water containing $1 \mathrm{ml}$ of ethanol solution of the tested insecticide. We should note that we used a series of five beakers in the case of control larvae and we added solely $1 \mathrm{ml}$ of ethanol. Burned results were obtained by counting the dead and living larvae after a contact time of $24 \mathrm{~h}$ with the insecticide tested. The test should be repeated if the number of death in control batch exceeded $10 \%$. The results of the sensitivity tests are expressed in the percentage of the larval mortality versus the concentrations of insecticides used.

\section{Biochemical assays}

Over-produced esterases were investigated on starch electrophoresis using the methods of Pasteur et $\mathrm{al}^{7}$.

\section{Data analysis}

Bioassays including synergist's tests were performed according to standard protocol of Raymond et $\mathrm{al}^{8}$. Data were subjected to probit analysis ${ }^{9}$ using a BASIC pro- 
gram ${ }^{10}$ to obtain $\mathrm{LC}_{50}, \mathrm{LC}_{95}$ and regression line. Values of $\mathrm{LC}_{50}, \mathrm{LC}_{95}$, confidence limits at $95 \%$ and slopes were computed. Susceptible strain was used to calculate the Resistance ratio at $\mathrm{LC}_{50}$ which is $\mathrm{LC}_{50}$ of field population/ $\mathrm{LC}_{50}$ of sensitive strain and synergism ratio at $\mathrm{LC}_{50}$ which is $\mathrm{LC}_{50}$ in absence of synergist/ $\mathrm{LC}_{50}$ in presence of synergist.

\section{Results}

The objective of the present study was to determine the resistance development and insecticide susceptibility in Culex pipiens pipiens against selection pressure of temephos and its relationship to cross-resistance towards organophosphate chlorpyrifos and pyrethroids permethrin.
The selection was initiated at the dose $0.0266,0.0748$ and 0.0069 which were increased during successive generations up to $0.1488,3.8747$ and 0.0086 in sixth generation for temephos, chlorpyrifos and permethrin insecticides, respectively (Tables $1,2,3$ ). It is important to note that high cross-resistance to chlorpyrifos insecticide (OP) was detected $(51.88 \times)$. However, little and no cross-resistance to the organophosphate temephos and pyrethroid permethrin (PYR) was recorded $(5.59 \times$ and $1.24 \times$, respectively). The little cross-resistance to the pyrethroid permethrin could support its use alternately for Culex pipiens pipiens control. However, the cross-resistance to chlorpyrifos from temephos selection could limit the use of both insecticides for Culex pipiens control.

Table 1: Temephos resistance status of selected laboratory population of Culex pipiens pipiens after temephos selection pressures

\begin{tabular}{|c|c|c|c|c|c|c|c|c|c|c|c|c|c|}
\hline \multirow[t]{3}{*}{ Population } & \multicolumn{3}{|c|}{ Temephos } & \multicolumn{5}{|c|}{ Temephos +DEF } & \multicolumn{5}{|c|}{ Temephos +Pb } \\
\hline & $\mathrm{LC}_{50}$ in $\mu \mathrm{g} / \mathrm{l}$ & Slope & $\mathrm{RR}_{50}$ & $\mathrm{LC}_{50}$ in $\mu \mathrm{g} / \mathrm{I}$ & Slope & $\mathrm{RR}_{50}$ & $\mathrm{SR}_{50}$ & RSR & $\mathrm{LC}_{50}$ in $\mu \mathrm{g} / \mathrm{I}$ & Slope & $\mathrm{RR}_{50}$ & $S_{50}$ & RSR \\
\hline & (a) & $\pm \mathrm{SE}$ & (a) & (a) & $\pm \mathrm{SE}$ & (a) & (a) & & (a) & $\pm \mathrm{SE}$ & (a) & (a) & \\
\hline Slab & $\begin{array}{c}0.0012 \\
(0.0011-0.0014)\end{array}$ & $\begin{aligned} & 2.34 \\
\pm & 0.22\end{aligned}$ & - & $\begin{array}{c}0.0003 \\
(0.0002-0.00036\end{array}$ & $\begin{array}{l}4.99 \pm \\
(0.69)\end{array}$ & - & $\begin{array}{c}3.84 \\
(2.89-5.09)\end{array}$ & - & $\begin{array}{c}0.0021 \\
(0.0017-0.0028)\end{array}$ & $\begin{array}{l}1.94 \pm \\
(0.28)\end{array}$ & - & $\begin{array}{c}0.56 \\
(0.44-0.72)\end{array}$ & - \\
\hline $\begin{array}{c}\text { Field } \\
\text { population }\end{array}$ & $\begin{array}{c}0.0266 \\
(0.0237-0.0301)\end{array}$ & $\begin{array}{r}3.02 \\
\pm 0.27\end{array}$ & $\begin{array}{c}21.45 \\
(17.63-26.10)\end{array}$ & - & - & - & - & - & - & - & - & - & - \\
\hline $\begin{array}{l}\text { Selected } \\
\text { population }\end{array}$ & $\begin{array}{c}0.1488 \\
(0.0887-0.2586)\end{array}$ & $\begin{array}{r}2.56^{*} \\
\pm 0.47\end{array}$ & $\begin{array}{c}119.64 \\
(82.08-174.39)\end{array}$ & $\begin{array}{c}0.1586 \\
(0.0993-0.2537)\end{array}$ & $\begin{array}{l}2.76 \pm \\
(0.54)\end{array}$ & $\begin{array}{c}489.90 \\
(278.99-860.24)\end{array}$ & $\begin{array}{c}0.93 \\
(0.53-1.65)\end{array}$ & 0.24 & $\begin{array}{c}0.1793 \\
(0.0002- \\
177.0710)\end{array}$ & $\begin{array}{c}1.80 \pm \\
(1.31)\end{array}$ & $\begin{array}{c}81.69 \\
(27.69-240.97)\end{array}$ & $\begin{array}{c}0.83 \\
(0.27-2.51)\end{array}$ & 1.46 \\
\hline
\end{tabular}

(a), $95 \% \mathrm{CI}$

$\mathrm{RR}_{50}$, resistance ratio at $\mathrm{LC}_{50}\left(\mathrm{RR}_{50}=\mathrm{LC}_{50}\right.$ of the population considered $/ \mathrm{LC}_{50}$ of Slab); $\mathrm{SR}_{50}$, synergism ratio $\left(\mathrm{LC}_{50}\right.$ observed in absence of synergist $/ \mathrm{LC}_{50}$ observed in presence of synergist). RR and SR considered significant $(\mathrm{P}<0.05)$ if their $95 \% \mathrm{CI}$ did not include the value 1 .

RSR, relative synergism ratio (RR for insecticide alone / RR for insecticide plus synergist). 
Table 2: Chlorpyrifos resistance status of selected laboratory population of Culex pipiens pipiens after temephos selection pressures

\begin{tabular}{|c|c|c|c|c|c|c|c|c|c|c|c|c|c|}
\hline \multirow[t]{3}{*}{ Population } & \multicolumn{3}{|c|}{ Chlorpyrifos } & \multicolumn{5}{|c|}{ Chlorpyrifos +DEF } & \multicolumn{5}{|c|}{ Chlorpyrifos + $\mathrm{Pb}$} \\
\hline & $\mathrm{LC}_{50}$ in $\mu \mathrm{g} / \mathrm{I}$ & Slope & $\mathrm{RR}_{50}$ & $\mathrm{LC}_{50}$ in $\mu \mathrm{g} / \mathrm{l}$ & Slope & $\mathrm{RR}_{50}$ & $\mathrm{SR}_{50}$ & RSR & $\mathrm{LC}_{50}$ in $\mu \mathrm{g} / \mathrm{I}$ & Slope & $\mathrm{RR}_{50}$ & $\mathrm{SR}_{50}$ & RSR \\
\hline & (a) & $\pm \mathrm{SE}$ & (a) & (a) & $\pm \mathrm{SE}$ & (a) & (a) & & (a) & $\pm \mathrm{SE}$ & (a) & (a) & \\
\hline Slab & $\begin{array}{c}0.00098 \\
(0.00089-0.0010)\end{array}$ & $\begin{array}{l}3.42 \pm \\
(0.29)\end{array}$ & - & $\begin{array}{c}0.00005 \\
(0.00004- \\
0.000055)\end{array}$ & $\begin{array}{l}3.31 \pm \\
(0.25)\end{array}$ & - & $\begin{array}{c}19.13 \\
(15.99-22.89)\end{array}$ & - & $\begin{array}{c}0.0045 \\
(0.0040-0.0051)\end{array}$ & $\begin{array}{r}2.75 \pm \\
(0.39)\end{array}$ & - & $\begin{array}{c}0.2159 \\
(0.1744- \\
0.2673)\end{array}$ & - \\
\hline $\begin{array}{c}\text { Field } \\
\text { population }\end{array}$ & $\begin{array}{c}0.0748 \\
(0.0420-0.1317)\end{array}$ & $\begin{array}{r}2.15 \pm \\
(0.42)\end{array}$ & $\begin{array}{c}75.90 \\
(48.46-118.87)\end{array}$ & - & - & - & - & - & - & - & - & - & - \\
\hline $\begin{array}{l}\text { Selected } \\
\text { population }\end{array}$ & $\begin{array}{c}3.8747 \\
(3.3426-4.5119)\end{array}$ & $\begin{array}{c}2.05 \pm \\
(0.16)\end{array}$ & $\begin{array}{c}3929.36 \\
(3212.09-4806.81)\end{array}$ & $\begin{array}{c}5.1234 \\
(4.3445-6.2644)\end{array}$ & $\begin{array}{l}2.43 \pm \\
(0.29)\end{array}$ & $\begin{array}{c}99435.21 \\
(80613.02- \\
186184.78)\end{array}$ & $\begin{array}{c}0.75 \\
(0.60-0.95)\end{array}$ & 0.04 & $\begin{array}{c}5.0581 \\
(4.1906-6.4375)\end{array}$ & $\begin{array}{r}2.03 \pm \\
(0.26)\end{array}$ & $\begin{array}{l}1107.5610 \\
(874.8061- \\
1402.2440)\end{array}$ & $\begin{array}{c}0.76 \\
(0.61-0.95)\end{array}$ & 3.54 \\
\hline
\end{tabular}

(a), $95 \% \mathrm{CI}$

$\mathrm{RR}_{50}$, resistance ratio at $\mathrm{LC}_{50}\left(\mathrm{RR}_{50}=\mathrm{LC}_{50}\right.$ of the population considered / $\mathrm{LC}_{50}$ of Slab); $\mathrm{SR}_{50}$, synergism ratio $\left(\mathrm{LC}_{50}\right.$ observed in absence of synergist $/ \mathrm{LC}_{50}$ observed in presence of synergist). RR and SR considered significant $(\mathrm{P}<0.05)$ if their $95 \% \mathrm{CI}$ did not include the value 1.

RSR, relative synergism ratio (RR for insecticide alone / RR for insecticide plus synergist).

Table 3: Permethrin resistance status of selected laboratory population of Culex pipiens pipiens after temephos selection pressures

\begin{tabular}{|c|c|c|c|c|c|c|c|c|c|c|c|c|c|}
\hline \multirow[t]{3}{*}{ Population } & \multicolumn{3}{|c|}{ Permethrin } & \multicolumn{5}{|c|}{ Permethrin +DEF } & \multicolumn{5}{|c|}{ Permethrin $+\mathrm{Pb}$} \\
\hline & $\mathrm{LC}_{50}$ in $\mu \mathrm{g} / \mathrm{I}$ & Slope & $\mathrm{RR}_{50}$ & $\mathrm{LC}_{50}$ in $\mu \mathrm{g} / \mathrm{I}$ & Slope & $\mathrm{RR}_{50}$ & $\mathrm{SR}_{50}$ & RSR & $\mathrm{LC}_{50}$ in $\mu \mathrm{g} / \mathrm{I}$ & Slope & $\mathrm{RR}_{50}$ & $\mathrm{SR}_{50}$ & RSR \\
\hline & (a) & $\pm \mathrm{SE}$ & (a) & (a) & $\pm \mathrm{SE}$ & (a) & (a) & & (a) & \pm SE & (a) & (a) & \\
\hline Slab & $\begin{array}{c}0.0004 \\
(0.0003-0.00044\end{array}$ & $\begin{array}{r}4.7 \pm \\
(0.55)\end{array}$ & - & $\begin{array}{c}0.0004 \\
(0.0002-0.0007)\end{array}$ & $\begin{array}{l}1.22 \pm \\
(0.25)\end{array}$ & - & $\begin{array}{c}0.99 \\
(0.73-1.33)\end{array}$ & - & $\begin{array}{c}0.0001 \\
(0.00009-0.00019)\end{array}$ & $\begin{array}{l}1.80 \pm \\
(0.26)\end{array}$ & - & $\begin{array}{c}3.08 \\
(2.28-4.16)\end{array}$ & - \\
\hline $\begin{array}{c}\text { Field } \\
\text { population }\end{array}$ & $\begin{array}{c}0.0069 \\
(0.0051-0.0092)\end{array}$ & $\begin{array}{l}5.64 \pm \\
(1.68)\end{array}$ & $\begin{array}{c}16.84 \\
(8.64-32.81)\end{array}$ & - & - & - & - & - & - & - & - & - & - \\
\hline $\begin{array}{l}\text { Selected } \\
\text { population }\end{array}$ & $\begin{array}{c}0.0086 \\
(0.0045-0.0165)\end{array}$ & $\begin{array}{l}2.09 \pm \\
(0.42)\end{array}$ & $\begin{array}{c}21.05 \\
(12.76-34.7)\end{array}$ & $\begin{array}{c}0.0086 \\
(0.0045-0.0167)\end{array}$ & $\begin{array}{l}2.43 \pm \\
(0.53)\end{array}$ & $\begin{array}{c}20.98 \\
(11.06-39.82)\end{array}$ & $\begin{array}{c}0.99 \\
(0.56-1.76)\end{array}$ & 1.00 & $\begin{array}{c}0.0020 \\
(0.0000-2.8515)\end{array}$ & $\begin{array}{r}1.68 \pm \\
(0.91)\end{array}$ & $\begin{array}{c}15.73 \\
(4.17-59.27)\end{array}$ & $\begin{array}{c}4.12 \\
(1.09-15.61)\end{array}$ & 1.33 \\
\hline
\end{tabular}

(a), $95 \% \mathrm{CI}$

$\mathrm{RR}_{50}$, resistance ratio at $\mathrm{LC}_{50}\left(\mathrm{RR}_{50}=\mathrm{LC}_{50}\right.$ of the population considered / $\mathrm{LC}_{50}$ of Slab); $\mathrm{SR}_{50}$, synergism ratio $\left(\mathrm{LC}_{50}\right.$ observed in absence of synergist / $\mathrm{LC}_{50}$ observed in presence of synergist). RR and SR considered significant $(\mathrm{P}<0.05)$ if their $95 \% \mathrm{CI}$ did not include the value 1 .

RSR, relative synergism ratio (RR for insecticide alone / RR for insecticide plus synergist). 
Organophosphates and pyrethroids insecticides confer the same resistance characteristics in the presence or absence of the synergists $\mathrm{DEF}$ and $\mathrm{Pb}$ in the selected strain. These observations indicate that the concerned gene does not code for increased detoxification by carboxylesterases or glutathione-S-transferases inhibited by DEF and/or cytochrome P450 oxidases inhibited by $\mathrm{Pb}$ ( $\mathrm{Ta}$ bles 1, 2, 3). Biochemical analysis confirmed these results and esterases were not detected. On the other hand, the correlation recorded between mortality due to carbamate propoxur and the $\mathrm{LC}_{50}$ of organopshosphate insecticides indicated an insensitive acetylcholinesterase (AChE1).

\section{Discussion}

It was found that the level of resistance in Culex pipiens pipiens submitted to the pressure of temephos insecticide after six generations had increased to 5 folds for temephos (OP) and 51 folds for chlorpyrifos (OP) without any cross-resistance to permethrin (PYR). Resistance to temephos and chlorpyrifos exhibited a significant difference in resistance towards $\mathrm{LC}_{50}$ values after six generations. It was not clear why such variations on the $\mathrm{LC}_{50}$ value was found, although they belong to the same insecticide class. Similar findings were found by previous studies on Culex pipiens submitted to different OPs insecticides $^{11-13}$. It is important to note that the parent larvae seemed moderately resistant to tested insecticides before pressure selection hence the possibility that these larvae had been subjected to some organic phosphate compounds. In this context, the resistance to chlorpyrifos in populations of Culex pipiens collected from Tunisia was high, reaching the highest level $>10,000$-folds recorded worldwide ${ }^{14}$. Wirth et $\mathrm{al}^{15}$ showed that under selection pressure to OPs insecticides, Culex mosquitoes displayed high levels of larval resistance to chlorpyrifos (64-fold), methyl parathion (57-fold), temphos (2-fold) and malathion (36-fold). High resistance to chlorpyrifos and other organophopshates insecticides was detected in regions submitted to excessive use of chlorpyrifos ${ }^{16}$. This finding was supported by previous studies showing the importance of the seasonal differences in chlorpyrifos resistance ${ }^{17}$. Little or no cross-resistance with permethrin insecticide was observed after six generations. These results could support its use alternately for Culex pipiens pipiens control and indicated that involved genes are not shared between the two insecticides classes. However, previous studies showed that different groups of genes can be selected with one insecticide ${ }^{18}$.

Based on finding of our investigation, we suggest some considerations for insecticide use. It is important to avoid long-term effects of repeated exposure to a constant low concentration of insecticide in Culex mosquitoes, because it can lead to dramatically increased resistance compared to its initial level. In the present study, the level of resistance to organophosphates insecticides significantly increased after six generation of selection. This finding indicated that both public health and agricultural applications may have negative impact on vector control. Therefore, it is important to reduce their use and choose chemical products with fast degradation in the environment to retard the development of resistance. The combination of chemical insecticides and synergists, inhibitor of detoxification enzymes, may also delay the increase of insecticides in high resistance areas ${ }^{19}$. It is important also to rotate the insecticides promptly having different modes of action before the occurrence of high resistance and cross-resistance with other classes of insecticides. On the other hand, it is important to note that insecticide withdrawal should be maintained for a long time like suggested by Raghavendra et $\mathrm{al}^{20}$. These authors showed that resistance to chemical insecticides may persist from 2 to 30 years after withdraw. Results of our study can be useful for current and future management of insecticide resistance in vectors and pests of public health importance.

The study of involved mechanisms showed the involvement of the target site without any detection of detoxification enzymes. Contrary to metabolic resistance, it seemed that AChE 1 was fixed under pressure selection. However, both target sites and metabolic resistance should be taken into account in vector control. In the present study, both chemical and synergism tests did not revealed any over-produced esterases to be involved in the recorded resistance to OPs insecticides. These detoxification enzymes were involved in the resistance to chlorpyrifos and temephos insecticides in Tunisian Culex pipiens $^{14,21,22}$. This correlation was found also in other mosquito's species including Aedes aegypti ${ }^{15}$. In this context, it is important to note that some enzymes are insensible to synergists like confirmed by Raymond et $\mathrm{al}^{23}$. These authors reported that the contribution of both target site 
and detoxification enzymes are additive although previous studies showed the dominance of target-site against resistance against OPs insecticide ${ }^{24}$. This finding can explain clearly our results and related the high resistance of the selected strain to the AChE1.

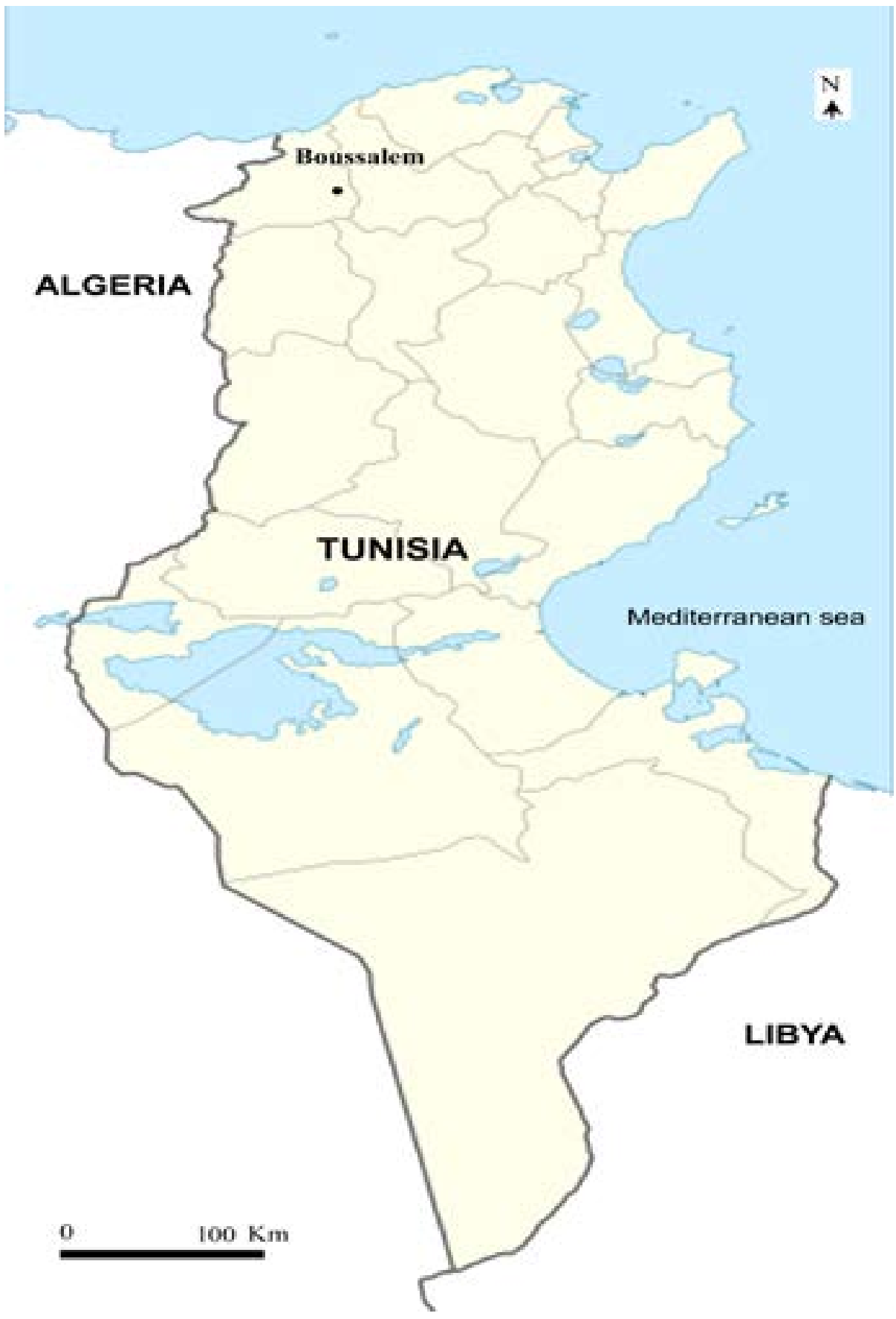

Figure 1: Geographic origin of the studied population.

\section{Acknowledgements}

This work was kindly supported by the Ministry of Higher Education and Scientific Research of Tunisia by funds allocated to the Research Unit (Génétique 02/UR/0803) and by DHMPE of the Minister of Public Health of Tunisia. We are very grateful to S Ouanes, for technical assistance, A Ben Haj Ayed and I Mkada for help in bioassays, S. Saïdi, Tunisian hygienist technicians for help in mosquito collecting, and M Nedhif and M. Rebhi for their kind interest and help.

\section{Conflict of interest statement}

The authors declare that they have no conflict of interest. 


\section{References}

1. Richard HF, David, R.C. Mosquitos of Medical Importance Washington D.C.: U.S. Department of Agriculture 1959.

2. Brattsten LB, Holyoke CW, Leeper JR, Raffa KF. Insecticide resistance: challenge to pest management and basic research. Science. 1986, 231: 1255-1260.

3. Georghiou GP, Pasteur N. Electrophoretic esterase patterns in insecticide-resistant and susceptible mosquitoes. Journal of Economic Entomology. 1978, 71(2): 201-205. 4. Lee HL, Tadano, T. Monitoring resistance gene frequency in Malaysian $C \times$. quinquefasciatus Say adults using rapid enzyme microassays. Southeast Asian Journal of Tropical Medicine and Public Health. 1994, 25(2): 371-373.

5. Georghiou GP, Metcalf RL, Gidden FE. Carbamate resistance in mosquitoes. Selection of Culex pipiens fatigans Wied for resistance to Baygon. Bull Word Health Organ. 1966, 35: 691-708.

6. Berticat C, Boquien G, Raymond M, Chevillon C. Insecticide resistance genes induce a mating competition cost in Culex pipiens mosquitoes. Genetics Research. 2002, 83: 189-196.

7. Pasteur N, Pasteur G, Catalan J, Bonhomme F, Britton-Davidian J. 1988. Practical isozyme genetics. Ellis Horwood, Chichester, United Kingdom.

8. Raymond M, Fournier D, Bride JM, Cuany A, Bergé J, Magnin M, Pasteur N. Identification of resistance mechanisms in Culex pipiens (Diptera: Culicidae) from southern France: insensitive acetylchlinesterase and detoxifying oxidases. Journal of Economic Entomology. 1986, 79: 1452-1458. 9. Finney DJ. 1971. Probit analysis. Cambridge University Press, Combridge.

10. Raymond M, Prato G, Ratsira D. PROBIT. 1993. Analysis of mortality assays displaying quantal response. Praxeme (Licence No. L93019), Saint Georges d'Orques, France.

11. Rathor HR, Togir . Mode of inheritance of malathion resistance in Anopheles stephensi Listion. Mosquitoes News. 1981, 41: 359-367.

12. Mostafa A. 1990. Toxicological studies on the larvae of Culex pipiens (L.). Ph.D. Thesis, Fac. Agric., Ain-Shams University.

13. Abdel-Badeeh D. 2001. A molecular study on the effect of some chemical insecticides on DNA of the mosquito, Culex pipiens. M. Sc. Fac. Sci., Ain-Shams University, Cairo, Egypt.

14. Ben Cheikh H, Ben Ali-Hauas Z, Marquine M, Pas-

African Health Sciences Vol 18 Issue 4, December, 2018 teur N. Resistance to organophosphorus and pyrethroid insecticides in Culex pipiens (Diptera: Culicidae) from Tunisia. Journal of Medical Entomology. 19980, 35: 251-260.

15. Wirth M, Georghiou GP, Pasteur N, Luna LL. Evaluation of resistance and change in relative density in a Culex tarsalis (Diptera: Culicidae) population under heavy insecticidal control. Journal of Medical Entomology. 1987, 24: 494-497.

16. Armes NJ, Jadhav DR, De Souza KR. A survey of insecticide resistance in $\mathrm{H}$. armigera in the Indian subcontinent. Bulletin of Entomology Research. 1996, 86: 499-514. 17. Kanga LHB, Pree DJ, Lier JLV, Walker GM. Management of insecticide resistance in oriental fruit moth Grapholita molesta; (Lepidoptera: Tortricidae) populations from Ontario. Pesticide Management of Sciences. 2003, 59: 921-927. 18. Selvi S, Edah MA, Nazni WA, Lee HL, Azahari AH. Resistance development and insecticide susceptibility in Culex quinquefasciatus against selection pressure of malathion and permethrin and its relationship to crossresistance towards propoxur. Tropical Biomedicine. 2005, 22(2): 103-113.

19. WHO position statement on integrated vector management to control malaria and lymphatic filariasis. Weekly Epidemiological Record. 2011, 86(13):121-7.

20. Raghavendra K, Verma V, Srivastava H, Gunasekaran K, Sreehari U, Dash A. Persistence of DDT, malathion \& deltamethrin resistance in Anopheles culicifacies after their sequential withdrawal from indoor residual spraying in Surat district, India. The Indian Journal of Medical Research. 2010, 132:260-4.

21. Daaboub J, Tabbabi A, Lamari A, Feriani F, Boubaker C, Ben Cheikh H. Levels of insecticide resistance to temephos, and associated mechanisms in Culexpipiens mosquitoes from central Tunisia, Journal of Mosquito Research. 2017a, 7(10): 79-83

22. Daaboub J, Tabbabi A, Lamari A, Feriani M, Boubaker C, Ben Ceikh H. Temephos Resistance in Three Populations of Culexpipiens Collected from Three Districts of Southern Tunisia and Its Significance for the Resistance Mechanism. Vector Biology Journal. 2017b, 2:1.

23. Raymond M, Heckel D, Scott JG. The interaction between pesticide genes. Model and experiment. Genetics. 1989, 123: 543-551.

24. Pasteur N, Marquine M, Ben Cheikh H, Bernard C, Bourguet D. A new mechanism conferring unprecedented high resistance to chlorpyrifos in Culex pipiens (Diptera: Culicidae). Journal of Medical Entomology. 1999, 36(6): 794-802. 